\title{
INTERCULTURAL HERMENEUTIC DIALOGUE BETWEEN CHILD AND ADULT IN DIVERSE EDUCATIONAL ENVIRONMENTS: THEORETICAL INSIGHTS
}

\author{
Inesa Vietien $\dot{e}^{1}$
}

\begin{abstract}
As economic, social, and political conditions are rapidly changing in modern society and the development of information and communication technologies is constantly in progress, attitudes toward children and their education are also transforming. Childhood education takes place in various environments through intercultural dialogue between child and adult, which is often interpreted in the context of communication theory. A dialogue between child and adult is also supplemented and enriched by hermeneutics in various environments. This dialogue enables the disclosure and understanding of the diversity of experiences of child and adult, learner and educator. Hermeneutics provides circumstances for childhood education to be perceived as a multidimensional and unique process. From the hermeneutic perspective, the intercultural dialogue between child and adult focuses on the problem of understanding in which the awareness of the whole, rather than participation and interaction, has particular importance in interpreting one's own experience and perception.
\end{abstract}

UDC Classification: 37.06; DOI: http://dx.doi.org/10.12955/cbup.v5.1041

Keywords: intercultural dialogue between child and adult, hermeneutics, diversity of educational environments.

\section{Introduction}

Childhood has a special meaning in today's society as children are the youngest and most socially dependent social group by age. They are fully dependent on adults who decide on the conditions that affect their life and education.

Modern childhood education, according to Monkevičienè (2009), is perceived as depending ever more clearly on the socio-cultural field between child and family, child and educator, family and educational institution, educational institution and community, child and social, as well as the cultural environment. Therefore, the quality of education is guaranteed by the complete intercultural hermeneutic dialogue between child and adult, and its expressions in various educational backgrounds. Various aspects of this process have been investigated and analysed by a number of foreign scholars from different perspectives (Sotirou, 2012, 1993; Schröer, 2009; Freire, 2009; Tanaka, 2005; Gillert, 2003; Yoshida \& Matsumoto, 2002; Schachinger, 2000; Sterfeldt \& Mathiasen, 1999; McLaughlin, 1997) and Lithuanian scholars and practitioners (Garšvė, 2014, 2012, 2011; Čičelis, 2013; Lukočiūtè, Mickutė, \& Mažeikis, 2009; Mažeikis \& Lenkauskaite, 2008; Martišauskienė, 2008; Duoblienè, 2006; Kontautienè, 2006; Juodaitytè, 2007, 2004, 2003, 2002; Bitinas, et al., 2004).

As a result of the rapid change of social life, childhood education depends on the mutual intercultural dialogue between child and adult in modern society.

The object of this research is the intercultural dialogue between child and adult in diverse educational environments.

The aim of the research is to reveal the intercultural dialogue between child and adult in diverse educational settings.

The objectives of the research are the following:

1. To provide the definition of hermeneutic dialogue by analyzing scientific literature; and

2. To reveal possibilities of intercultural dialogue between child and adult in diverse educational environments.

\section{Methods}

The methods in this research involved an analysis of scientific literature and meta-analysis.

\section{Hermeneutics and Dialogue}

Hermeneutics literary means 'interpretation and understanding'. In philosophy, this concept is treated as a doctrine for the conditions in interpreting meaning and the objects of the interpretation and their meanings (Juodaityte \& Savickis, 2013). According to Heidegger (1988), hermeneutics encompasses the combination of objects interpreted as well as the practical application of interpretation.

\footnotetext{
${ }^{1}$ Šiauliai University, Lithuania, inesa.w@gmail.com
} 
Hermeneutics, on the one hand, is educational philosophy, while on the other hand, it refers to the method of education, which may be revealed in various ways, depending on the circumstances. It is the philosophy of understanding that explains the evolution of human understanding. Hermeneutics is focused on the revelation of meaning in the actions of an individual (Garšvè, 2014). Understanding actions and plans is an objective of one of its features. Hermeneutics is based on the objectivity of understanding actions as well as pragmatism and dialogism. Understanding only appears as a result of constant interpretation of experience. Only when a shift from false images to that which are 'right' is understanding reached. In this case, 'right' understanding is perceived pragmatically as properness and functionality, as opposed to the normal meaning (Mažeikis \& Lenkauskaite, 2008).

Hermeneutics refers to dialogue as providing the possibility for two subjects to communicate. Understanding refers to interpretation and hermeneutics refers to a method to discover conditions in which understanding takes place (Gadamer, 2004).

Dialogue is a phenomenon that enables a person to interpret the world, by instinctively looking for another individual with whom to communicate or transfer past experience, accumulated emotions, render experiences, or express one's opinion. Dialogue takes place not only verbally, but also through body language, facial expressions, movements, and forms (Čičelis, 2013).

According to Gutauskas (2010), dialogue is an essential part of human existence that has major significance. This concept can be encountered in politics, science, work, meetings, conferences, and daily life. Dialogue is understood as a linking unit that allows people to understand each other better, to reach agreements, and to work together. Dialogue, as a process, is a conversation between two or more people; it is a meeting situation, with physical interaction, and a presence in front of one or more others in which something is discussed. Shared meanings appear in the conversation, as well as the sphere of understanding and agreement. Dialogue involves two or more partners talking, addressing each other, understanding something in a common way and reaching agreement on a subject. In relation to these aspects, dialogue is communication, mutual understanding, and agreement.

Rau (2005) claims that dialogue is a way of communicating that creates conditions for common understanding and gives meaning to human relationships. When writing about cultural dialogue, the author emphasizes the process of dialogue where the participants view each other sincerely. It starts when the feeling of self-esteem and self-respect between them is consciously the same. There is no dialogue between the 'strong' and the 'weak' participants because the 'strong' participant tries to ignore the 'weak' one and impose their own worldview on the other. Participants of dialogue need to know who they are, on whose behalf they are speaking, what their story is, and how they are perceived by others. This process is impossible without tolerance, which helps people of entirely different ethnic, cultural, religious, or political origins who want to live together too, not only be together, but also arrive at a mutual agreement in today's society.

Mažeikis and Lenkauskaitè (2008) noticed that dialogue has a logic of evolution and goes beyond the boundaries of personal attitudes, thus widening the horizons of understanding and explanation. Dialogue in itself, without the recognition of its development and conclusions, is not a sufficient act of understanding, as it is only fulfilled upon recognition. Sotirou (1993) claimed that the most important feature of dialogue is its interpretation, which is analyzed by at least two persons. The author notes that understanding only appears upon partnership and dialogue.

In can be concluded that dialogue is frequently considered in the theory of communication by questioning the ways and forms information is transmitted to find the correct and effective communication potentially. However, dialogue is one of the most universal and interesting experiences. From the hermeneutic perspective, dialogue has become the completion of meaning and the acquisition of understanding rather than the opening of meaning.

\section{Expression of Dialogue Between Child and Adult in Informal Educational Environment}

Under the current conditions of constant change where one needs to adapt to the post-modern existence, the understanding of childhood requires "the new post-modern knowing and understanding" (Gellner, 1993, p. 93), which can be revealed using hermeneutics. Not only does hermeneutics clarify the meanings of childhood, but it also forms the understanding (Klawki, 1991).

A family is an integral factor of education and the closest environment surrounding the child where his or her attitude towards people, environment, world, and himself or herself is formed. The child's 
features, talents, and preferences come to light, and sense and sensibility are formed. The child gains his or her first experience, first impressions, acquires first knowledge, abilities, and skills in his or her way (Žilionis, 2003; Matulienè, 1997). According to Martišauskienè (2008), the family is the first educator of the child. The child learns many phenomena in the family before he or she starts attending a pre-school establishment. Not only do children gain their first skills, first knowledge and abilities here, but also, they form their emotions and communication experiences here.

Education in childhood centers around children's social cognitive experience, and children become the context of the constantly evolving social interaction with the environment. Such education is vital not only for the children but also for the family because people perceive it as a dialogue between two cultures (children and adults). Dialogue refers to the development of a joint project in the social life of adults and children, titled 'here and now.' People direct it towards solving social tasks essential for the child in the micro-environment, as a habit of solving by interaction between both groups of individuals, namely adults and children who have a different experience. It, thus, establishes their training in solidarity for dealing with human problems. The intercultural dialogue between children and adults (parents) gives meaning to their interconnection (Juodaityte, 2003).

Glebuvienè, Grigaite, and Monkevičienè (2002) emphasize that the dialogue interaction between an adult and a child should enable the revelation of the child's self-image and self-respect. Also, it should encourage harmonious relationships of the child with the environment, the surrounding people, and him- or herself, rather than the child's cognitive development. According to the authors, the basis for this interaction is the rapid response of the adult to the child's needs, desires, and requests. This response includes the adult's constant focus on his or her own activities, provision of circumstances for the child to communicate, the development of emotional contact in recognizing the child, by no way, or rarely, emphasizing the child's improper behavior.

Therefore, cultural, social, and spiritual development in childhood is relevant in the post-modern society. Hence, it becomes particularly significant in childhood education. The family is the closest environment surrounding the child where he or she learns values, attitudes, and ideals as well as key social competencies and skills. Childhood education in the informal environment takes place by maintaining an open dialogue between the two cultures, i. e., the dialogue between child and adult, where the most important custom is to focus on the child's experience constantly.

\section{Expression of Dialogue Between Child and Adult in Formal Educational Environment}

Following the post-modern ideas, education needs an entirely new thinking regarding its theory and the relationship between theory and practice. There is no clear situation, plan, or results in the education process (Fullan, 1998). An undefined movement where the plan is corrected is also possible when the action is already in progress, and the result is not the most important element of this process. The meaning of self-creation is apparent in the post-modern context (Rubavičius, 2003). According to Juodaityte (2003), reconsidering the complex relations of the child-adult system is possible.

According to Duoblienè (2006), modern childhood education is based on the principle of dialogue by emphasizing the reconsideration of one's own position and assumptions as well as power games. Where dialogue is based on questions and answers it is important to acknowledge differences and treat each other as partners in achieving equal intercultural dialogue in the education process.

Once education perceives different intercultural experiences, the most common obstacle is the lack of knowledge and inability of participants to accept others. This result creates a dearth of conditions for intercultural dialogue. As noticed by Godon (2004), hermeneutics encompasses three main elements in education that are among the most important factors in educating children when reflecting on different experiences: understanding, personal identity, and learning. It makes it possible to understand and analyze the education of 'different' children as well as issues that arise from the absence of bilateral dialogue between the educator and learners. Therefore, hermeneutics in education would serve to help individuals understand the differences between children of varying cultures and for organizing education in a way that the child and the adult are equal partners rather having an inequitable standpoint. Hermeneutics facilitates the change needed in understanding learners and educators in education (Garšvè, 2011; Lukočiūtè et al., 2009).

Intercultural dialogue in a formal education environment facilitates an understanding of differences among educators and learners, i. e., moving away from the educator as the subject and the learner as 
the object. Two models were chosen to understand this relationship: The typology of ethnics by Banks (1994) and the model of intercultural sensitivity by Milton Bennett (1993). Both focus on education. The process-oriented model of Bennet (1993) shows how perceiving the cultural identity of other changes the participants and how dialogue creates favorable conditions in education. The processoriented model also helps structure the educator's behavior, habits, and relationship with the learner (Freire, 2009). As claimed by Banks (1994), a variety of experiences progress, i. e., interactive education methods are used. These methods include simulation and communication with representatives of another culture for reflection of experiences.

According to Garšvė (2014), education in a formal environment is not static; it is a dynamic process that hermeneutics can enrich. According to the author, education does not reflect superstitions and stereotypes and thus, contains illusions. Hermeneutics focuses on analyzing superstitions, habits, and illusions by trying to perceive them critically instead of rejecting them. It also emphasizes the search and revelation of meaning for participants of education who reflect on different experiences. As well, it emphasizes the importance of the child in formal education, constantly focusing on the child's experience, and encourages the child to become involved in improving his or her experience (Juodaitytè, 2003).

Hermeneutics, according to Garšvè (2014), is a method for understanding and explaining experience. The explanation of meanings is relatively lively and undefined. The sphere of the hermeneutic strategy is extensive, and it opens broad horizons. The strategy is based on the principle that education is the synthesis of horizons where it is important to hear the voice of another upon an encounter with traditions. The encounter is perceived as one between the individual who knows and the points the individual learns; the learner and his or her object of learning. Knowledge and language play a major role in this synthesis of horizons (Fairfield, 2011).

The role of a hermeneutic educator in formal education encompasses three major layers: a) the change in the position of the educator in the learning process; b) a critical dialogue relationship within the sociocultural, political, economic, and technological environments; and c) the constant need of the educator to learn and improve. First, the hermeneutic educator, the former traditional educator, i. e., the educator as the organizer of education, becomes the assistant of learners and moves towards selfunderstanding. In this, the educator is an assistant establishing a link between the experiences of learners in order for them to be understood. This relationship is directed towards openness, risk taking, misunderstandings, and surprise, which influence the dialectal link between knowing and otherness. Second, the role of the hermeneutic educator allows use of new information technologies in education, as well as the critical, creative relationship with misinformation, addictions, and social abnormalities (for instance, personal isolation). The role of educator as the interpreter of cultures is paramount. Third, the role of the hermeneutic educator should be based on creative self-education. This can be achieved by focusing on literature, bodily movements, artistic expression, improvisation, to help interpret and develop cognitive abilities to accept the revelation of otherness in the context of existentialism (Garšvė, 2014; Duoblienè, 2006a; Fullan, 1998).

The hermeneutic method explains the multiplicity of human existence in the world as well as the multiplicity of education, and it paves the way to dialogue between 'I' and 'You,' e.g., the child and the adult. Dialogue makes it possible to gradually overcome miscommunication (Juodaityte் \& Savickis, 2013). Hermeneutics involves interpreting and adapting the experience of education and its practical application in a particular context. The educator can transfer an understanding of an object using reflection as well as broaden a previous understanding, since it is constantly improved through reflection (Mažeikis \& Lenkauskaitè, 2008).

According to Duobliene (2006), hermeneutics actualizes the principle of improving interpretation skills in education. The interpretative act is not based on role models; it is a free, playful process that maintains dialogue to achieve a different understanding of reality. There is no final word in such an environment. Dialogue helps avoid obligatory consensus and increases involvement (Mažeikis \& Lenkauskaitè, 2008).

Therefore, modern childhood education in the formal environment is based on a principle of international dialogue that is supplemented and enriched by hermeneutics. Hermeneutics creates conditions in a formal environment for childhood education to be perceived as a unique 
multidimensional process from the perspective of various cultures in the context of current global developments.

\section{Conclusions}

Dialogue is one of the most universal and interesting experiences, established and developed to alter and discover new meanings and to interpret experiences using communication. The hermeneutic dialogue focuses on the problem of understanding, where awareness of the whole, rather than participating and interacting, has particular significance.

Dialogue, as the main form of communication between a child and an adult, occurs in various educational environments, both formal and informal, where a constant focus on the child's experience is considered crucial.

Modern childhood education involves intercultural dialogue, which hermeneutics enriches. Hermeneutics enables the revelation of change in the understanding of child and adult, learner and educator, and reflecting on different experiences. In applying the hermeneutic method, dialogue becomes a scheme of questions and answers where recognizing differences and the treatment of another as an equal partner become important. Therefore, the intercultural dialogue between a child and an adult in various educational environments enables the revelation and understanding of diversity in experiences of child and adult, learner and educator.

\section{References}

Banks, J. (1994). Multi-ethnic Education: Theory and practice. Needham Heights, MA: Allynand Bacon.

Bennett, M. J. (1993). A development approach to training for intercultural sensitivity. International Journal of Intercultural Relations, 10, 179-195.

Bitinas, B. (2004). Hodegetika. Auklejjimo teorija ir technologija [Hodegetics. Theory and Technology of Education]. Vilnius: Kronta.

Čičelis, R. (2013). Dialogas ir hermeneutikos tradicija [Dialogue and Hermeneutic Tradition]. Colloquia, 32, 180-185.

Duobliené, L. (2006). Šiuolaikinė ugdymo filosofija: refleksijos ir dialogo link [Modern Education Philosophy: Towards Reflection and Dialogue]. Vilnius: Tyto alba.

Duoblienè, L. (2006a). Tarpkultūrinis ugdymas: tautinio tapatumo ir/ar dialogo su Kitu paieškos. Lietuva globalèjančiame pasaulyje [Intercultural Education: Searching for National Identity and/or Dialogue with the Other. Lithuania in the Globalised World]. Vilnius: Logos.

Fairfield, P. (2011). Dialogue in the Classroom. Education, Dialogue and Hermeneutics. Continuum International Publishing Group: New York, 77-90.

Freire, P. (2009). From Pedagogy of the Oppressed. Race/Ethnicity: Multidisciplinary Global Perspectives, 2(2), 163-174.

Fullan, M. (1998). Pokyčiu jègos [Powers of Changes]. Vilnius: Tyto alba.

Gadamer, H. G. (2004). Truth and Method. London: Continuum Publishing Group.

Garšvė, L. (2011). Lietuvių kilmės mokinių identitetų ugdymas: naujojo diskurso konstravimas remiantis postmodernosiomis filosofijos teorijomis [Upbringing Identities of Pupils of Lithuanian Origin: Structuring the New Discourse on the Basis of Post-modern Philosophical Theories]. Mokytojų ugdymas [Teacher education], 17(2), 25-37.

Garšvė, L. (2012). Tautinio tapatumo slinktys postmodernioje visuomenejje [Articulations of National Identity in Postmodern Society]. Jaunųjų mokslininkų darbai [Young Scientists], 5(38), 64-68.

Garšvė, L. (2014). Hermeneutinė pedagogika kaip edukologijos metodologija. Šiuolaikinès hermeneutikos iššūkiai ir problemos [Hermeneutic Pedagogy as Methodology of Education. Challenges and Issues of Modern Hermeneutics], 17, 175 188.

Gellner, E. (1993). Postmodernizmas, protas ir religija [Post-modernism, Reason and Religion]. Vilnius: Pradai.

Gillert, A. (2003). Intercultural Learning T-kit. Nr. 4. Retrieved from http://pjp-eu.coe.int/documents/1017981/1667917/ tkit4.pdf/1e4f2f12-6448-4950-b0fd5f4c94da38 e2

Glebuvienè, V., Grigaitè, B. \& Monkevičienė, O. (Eds.) (2002). Lietuvos vaikų brandumas mokyklai: tyrimas ir problemos [Lithuanian Children's Maturity for School: Research and Issues]. Vilnius: Švietimo aprūpinimo centras.

Godon, R. (2004). Understanding, Personal Identity and Education. Journal of Philosophy of Education, 38(4), 589-600.

Gutauskas, M. (2010). Dialogo erdvė. Fenomenologinis požiūris [Dialogue space. Phenomenological Approach]. Vilnius: Vilniaus universiteto leidykla.

Heidegger, M. (1988). Ontology: The Hermeneutics of Facticity.

Juodaitytė, A. \& Savickis, A. (2013). Hermeneutikos metodo taikymas šiuolaikiniame edukologijos moksle [Application of Hermeneutic Method in Modern Education Science]. Acta Pedagogica Vilnensia [Acta pedagógico Vilnensia], 30, 24-33.

Juodaitytė, A. (2002). Socializacija ir ugdymas vaikysteje [Socialisation and Childhood Education]. Vilnius: Petro ofsetas. 
Juodaitytè, A. (2003). Vaikystès fenomenas: socialinis-edukacinis aspektas [Childhood Phenomenon: Social-educational Aspect]. Šiauliai: Šiaulių universiteto leidykla.

Juodaitytè, A. (2004). Vaikystės pedagogo pasaulèžiūrinè koncepcija: ,laisvojo“ ugdymo kontekstas [Worldview Concept of Childhood Educator: Context of "Free" Education]. Pedagogika [Pedagogy], 70, 87-91.

Juodaitytė, A. (2007). Vaikystė kaip socialinè negalė: mitologizuoto diskurso konstravimas ir sklaida socialinėje, pedagoginëje realybeje [Childhood as Social Disability: Structuring and Disseminating Mythologised Discourse in Social and Pedagogic Realty]. Socialinis darbas [Social Work], 6(1), 104-112.

Klawki, W. (1991). Erziehungswissenschaft des Kritischkonstruktive theory: Hermaneutik - Empiric - Ideologiekritik [Critical Constructural Theory: Hermaneutics - Empiric - Ideology Criticism]. Zeitchrift für Pädagogik [Pedagogy], 3.

Kontautienè, R. (2006). Bendradarbiavimo sistema ir jos valdymas mokykloje [Cooperation System and its Management at School]. Klaipèda: Klaipėdos universiteto leidykla.

Lukočiūtè, L., Mažeikis, G. \& Mickutè, R. (2009). Hermeneutinè klasė: iš užsienio grižusių mokinių tapatybès švytuoklè ir jos supratimas [Hermeneutic Class: Pendulum of Identity of Pupils Returning from Abroad and its Understanding]. Jaunuju mokslininkų darbai [Young Scientists], 4(25), 44-49.

Martišauskiene, E. (2008). Ugdomojo mokymo retrospektyva ir dabartis (V. Rajecko „Ugdomojo mokymo“ ir konstruktyvizmo paralelès) [Retrospectives and Presence of Educational Training (V. Rajeckas' Parallels of "Educational Training" and Constructivist Parallels)]. Pedagogika [Pedagogy], 89, 11-17.

Matulienè, G. (1997). Šeimos psichologija [Family Psychology]. Kaunas: Technologija.

Mažeikis, G. \& Lenkauskaitè, J. (2008). Dėstytojų gebėjimai adaptuoti kooperuotų studijų metodą: Šiaulių universiteto, Šiauliu bei Panevėžio kolegiju patirtis [Professors' Abilities to Adapt the Cooperative Learning Method: Experience of Šiauliai University, Šiauliai College and Panevėžys College]. Jaunųų mokslininkų darbai [Young Scientists], 1(17), 82-88.

McLaughlin, T. (1997). Šiuolaikinė ugdymo filosofija: demokratiškumas, vertybės, įvairovė [Modern Education Philosophy: Democratic Character, Values, Diversity]. Kaunas: Technologija.

Monkevičienè, O. (2009). Lietuvos švietimo reforma: ikimokyklinio ugdymo turinio ir pedagoginių technologijų kaita 1988 2008 [Lithuanian Educational Reform: Change of the Content of Pre-school Education and Pedagogic Technologies 19882008]. Mokytojų ugdymas [Teacher education], 12(1), 104-120.

Rau, J. (2005). Kultūrų dialogas - dialogo kultūra. Tolerancija vietoj nureikšminimo [Dialogue of Cultures - Culture of Dialogue. Tolerance instead of Depreciation of Meaning]. Vilnius: Dialogo kultūros institutas.

Rubavičius, V. (2003). Postmodernusis diskursas: filosofinė hermeneutika, dekonstrukcija, menas [Post-modern Discourse: Philosophical Hermeneutics, Deconstruction, Art]. Vilnius: Kultūros, filosofijos ir meno institutas.

Schachinger, W. (2000). Limiting distributions for the costs of partial match retrievals in multidimensional tries. Random Structures \& Algorithms, 17, 428-459.

Schröer, N. (2009). Hermeneutic Sociology of Knowledge for Intercultural Understanding. Forum Qualitative Social forschung/Forum: Qualitative Social Research, 10(1).

Sotirou, P. (1993). Articulatinga Hermeneutic Pedagogy: The Philosophy of Interpretation. Journal of Advanced Composition.

Sotirou, P. E. (2012). The Pedagogical Implications of Hans-Georg Gadamer's Hermeneutics: Alternatives for Teaching Students. How to Readand Write? United States: Edwin Mellen Press.

Sterfeld, E. \& Mathiasen, C., R. (1999). Pedagogika ir demokratija/Ugdomojo darbo eksperimentai Lietuvos vaiku darželiuose [Pedagogy and Democracy/Educational Experiments in Lithuanian Kindergartens]. Vilnius: Aidai.

Tanaka, M. (2005). The Cross-Cultural Transfer of Educational Concepts and Practices: A Comparative Study. Oxford: Symposium Books.

Yoshida, T. \& Matsumoto, D. (2002). The Japanese Returnee experience: factors that affect re-entry. International Journal of Intercultural Relations, 26(4), 429-445.

Žilionis, J. (2003). Ugdymo sistemos: ikiinstitucinis ugdymas, antika, viduramžiai, renesansas [Education Systems: Preinstitutional Education, Antiquity, the Middle Ages, the Renaissance]. Vilnius: VPU leidykla. 